\title{
Ready for Patenting ${ }^{1}$
}

\author{
Mark A. Lemley ${ }^{2}$
}

We give patents to inventors to reward and therefore encourage innovation. But what is the act of invention? Am I an inventor when I think of an idea? Or am I an inventor only when I actually get my invention to work, by building something or putting a process into practice? Courts and scholars have long struggled with the question of whether invention is primarily a mental act or instead primarily an act of building it - what patent law calls "reducing an invention to practice." ${ }^{3}$ William Robinson, the author of the leading nineteenth-century patent treatise, thought the most important act of invention was mental - the formation in the mind of a new idea. ${ }^{4}$ For Robinson, as long as an idea was "practical" and "operative" the act of writing it down in a patent was enough to give the benefit of it to the world. ${ }^{5}$ Justice Story, by contrast, saw the inventor's central contribution as introducing new technology to the world, something that could only happen when the idea had been turned into a working, usable device

1 C 2015 Mark A. Lemley.

2 William H. Neukom Professor, Stanford Law School; partner, Durie Tangri LLP. Thanks to Chris Cotropia, Kristy Downing, Rochelle Dreyfuss, John Duffy, John Golden, Rose Hagan, Tim Holbrook, Dmitry Karshtedt, Michael Martin, Lisa Ouellette, Michael Risch, Josh Sarnoff, Dave Schwartz, Jake Sherkow, Gary Shuster, Ted Sichelman, and participants at the 2015 IP Scholars' Conference for comments on an earlier draft.

335 U.S.C. $§ 102$ (g) (2010 edition). For discussions, see, e.g., Christopher A. Cotropia, What is the "Invention," 53 Wm. \& Mary L. Rev. 1855 (2012).

41 William Robinson, Robinson on Patents $\S 80$ (1890) ("To him alone whose mind conceives the perfect, practical, operative idea - that idea which, when embodied in tangible materials, will accomplish the desired result - belongs the right of the inventor and the credit of performing the inventive act."

5 Id. 
or method. ${ }^{6}$ Interestingly, both agreed on one thing: Paper patentees - those who never made anything - were not sufficiently advancing the progress of the useful arts. ${ }^{7}$

Patent law has tried to find a middle ground between these two visions of invention.

The definition of invention in the 1952 Patent Act incorporates both conception and reduction to practice, sometimes choosing the first to conceive as the inventor and at other times choosing the first to reduce an invention to practice. ${ }^{8}$ But in trying to walk that middle ground, patent law has not actually encouraged inventors from getting their inventions to work in practice, rewarding instead those who run to the patent office before they are fully done with the invention and giving them precedence over those who take the time to make sure their invention works by building and testing it. ${ }^{9}$ In an important class of cases - those in which the inventor has an idea but does not yet know if it will work - the patent system encourages the inventor to patent first and figure it out later, if at all. And precisely because those inventors haven't yet figured out what works, both the information their patents disclose and their

6 Earle v. Sawyer, 8 F. Cas. 254 (C.C.D. Mass. 1825) (Story, J.) ("The thing to be patented is not a mere elementary principle, or intellectual discovery, but a principle put in practice, and applied to some art, machine, manufacture, or composition of matter. . . The law looks to the fact [of application], and not to the process by which it is accomplished.").

7 Id. For a discussion of paper patents, see John F. Duffy, Reviving the Paper Patent Doctrine, 98 Cornell L. Rev. 1359 (2013).

To be sure, there is more nuance here than is portrayed in the text. A sufficiently detailed set of instructions could be viewed as introducing a new technology even if the inventor wasn't the one who actually built it. In theory, a patent ought to provide that sufficiently detailed set of instructions, though as I explain below it often doesn't.

835 U.S.C. § 102(g) (2000).

9 In so doing, the law has implicitly adopted Ed Kitch's prospect theory of the patent system, which gives broad rights to early inventors in hopes that they will then be incented to develop the invention. Edmund Kitch, The Nature and Function of the Patent System, 20 J.L. \& Econ. 265 (1977). For criticism of that theory, see, e.g., Mark A. Lemley, The Economics of Improvement in Intellectual Property Law, 75 Tex. L. Rev. 989 (1997); Robert P. Merges \& Richard R. Nelson, On the Complex Economics of Patent Scope, 90 Colum. L. Rev. 839 (1990). 
patent claims tend to be more general, giving them broader rights than those who take the time to build and patent a working invention. The problem is even worse under the new America Invents Act passed in 2011, which encourages patentees to file their applications as soon as possible. ${ }^{10}$ Indeed, those who actually build and test an invention under the new statute before filing a patent application may even find that they have lost their rights by doing so.

The fact that the law encourages inventors to file first and figure out later how (or even if) the invention works for its intended purpose is unfortunate. It produces underdeveloped patent applications that do not communicate useful information to the world. It facilitates the rise of patent trolls who obtain patents but never bother to produce a product, instead making a business of suing those who do. And it pushes people to patent things just in case, adding more patents into a system already overburdened with them. ${ }^{11}$

Some have suggested that we should require patentees to actually make products ${ }^{12}$ or at least build and test prototypes before filing their patent applications. ${ }^{13}$ But doing so would

1035 U.S.C. $\S 102$ (2011).

11 One reason to patent early is to have something of legal significance to offer in licensing negotiations, helping to overcome Arrow's information paradox. See Kenneth J. Arrow, Economic Welfare and the Allocation of Resources for Invention, in The Rate and Direction of Inventive Activity: Economic and Social Factors 609, 614-16 (1962). As I have argued elsewhere, however, patents are not the only solution to the paradox. Inventors can and do bargain around trade secret rights as well. Mark A. Lemley, The Surprising Virtues of Treating Trade Secrets as IP Rights, 61 Stan. L. Rev. 311 (2008).

12 See, e.g., Richard A. Posner, Patent Trolls Be Gone, Slate, October 15, 2012, http://www.slate.com/articles/news and politics/view from chicago/2012/10/patent protection ho $\mathrm{w}$ to fix it.html; J. Yosick, Compulsory Patent Licensing for the Efficient Use of Inventions, 2001 U. III. L. Rev. 1275.

13 Christopher A. Cotropia, The Folly of Early Filing in Patent Law, 61 Hastings L.J. 65 (2009). Notably, the PTO used to require the submission of models of an invention in the early $19^{\text {th }}$ century. See, e.g., The Commissioner of Patents on Models, 38:8 Sci. Am. 113 (Feb. 23, 1878) (discussing the history of the model requirement and why it was no longer needed). 
have its own worrisome consequences, not least the fact that a scientific article could invalidate a patent without itself containing enough information to permit its author to file a patent. And actually making things seems likely to become less important as physical production becomes routine in a world with ubiquitous $3 \mathrm{D}$ printing. ${ }^{14}$ The result is a difficult problem for patent doctrine, one that is only exacerbated by the coming wave of cases under the America Invents Act. But whatever the right answer to that problem, we should not be in the position in which we currently find ourselves: treating inventors less favorably if they try to build and test their inventions. ${ }^{15}$

In Part I, I walk through the often-confusing rules in the 1952 Act that determine what an inventor must show and when an invention is ready for patenting, and demonstrate that the regime we have created favors those who patent before building and testing a prototype. In Part II, I explore how the new patent rules in the AIA potentially exacerbate this problem. In Part III, I consider some possible solutions designed to encourage inventors to implement and test their ideas.

\section{The 1952 Act: “Will Work for Its Intended Purpose”}

Under the 1952 Act, the key triggering event associated with a patent is the date of invention. As between two competing patent applicants, the 1952 Act (which applies to patent

14 See, e.g., Mark A. Lemley, IP in a World Without Scarcity, 90 N.Y.U. L. Rev. 460 (2015).

15 Others have suggested treating those who don't make products less favorably under the law. See, e.g., John F. Duffy, Reviving the Paper Patent Doctrine, 98 Cornell L. Rev. 1359 (2013). More on this later. 
applications filed before March 16, 2013) ${ }^{16}$ awarded the patent to the first to invent it. And when a patent examiner or an accused infringer argues that the patent is not valid because the invention is disclosed in the prior art, the patentee can avoid that prior art by showing that they invented before the effective date of that prior art. ${ }^{17}$

But what exactly is "invention"? Historically the answer has involved the actual making of a device that works. The goal of patent law on this view is the contribution of a tangible, practical thing to the world. The Supreme Court in the Nineteenth Century held that an invention was not complete until it had been reduced to practice:

Crude and imperfect experiments are not sufficient to confer a right to a patent; but in order to constitute an invention, the party must have proceeded so far as to have reduced his idea to practice, and embodied it in some distinct form. ${ }^{18}$

Inventions on this view often start as ideas - though not always; many important inventions in history were accidental. ${ }^{19}$ But they are not inventions until they actually result in a tangible thing or a process that operates on and transforms the real world. ${ }^{20}$ On this view, an invention

16 See Man. Pat. Examining Proc. $\$ 2159$ (discussing transition dates).

1735 U.S.C. §102(g) (2010 edition); 37 C.F.R. §1.131.

18 Seymour v. Osborne, 78 U.S. 516, 522 (1871). See also Clark Thread Co v. Willimantic Linen Co., 140 U.S. 481, 489 (1891) ("It is evident that the invention was not completed until the construction of the machine."); Earle v. Sawyer, 8 F. Cas. 254 (C.C.D. Mass. 1825) (Story, J.).

The issue is complicated by the fact that in the early part of the $19^{\text {th }}$ century patent claims were not intended to define the outer bounds of the invention, but rather to identify the central thing invented. See Dan L. Burk \& Mark A. Lemley, Fence Posts or Sign Posts? Rethinking Patent Claim Construction, 157 U. Pa. L. Rev. 1743 (2009). For a discussion of the complications of this doctrine in an era before peripheral claiming, see Joshua D. Sarnoff, The Historic and Modern Doctrines of Equivalents and Claiming the Future, Part I (1790-1870), 87 J. Pat. \& Trademark Ofc. Soc'y 371, 386-91 (2005).

19 For a discussion of a number of prominent examples, see Mark A. Lemley, The Myth of the Sole Inventor, 110 Mich. L. Rev. 709 (2012); Sean Seymore, Serendipity, 88 N.C. L. Rev. 185 (2009).

20 Cf. Corona Cord Tire Co. v. Dovan Chem. Corp., 276 U.S. 358, 382 (1928) (commercialization of the invention was not required, but "the necessary reduction to use" could be proven by showing that the invention did work as described); Ultramercial, Inc. v. Hulu LLC, 772 F.3d 709 (Fed. Cir. 2014) (Mayer, J., 
requires reducing an idea to a tangible thing that actually works for its intended purpose - that achieves something useful in the world. Those who do that are inventors; those who don't may be smart and may even advance knowledge but they haven't made the world a better place.

Reduction to practice in this sense does not necessarily require that the patentee commercialize the invention. ${ }^{21}$ But it requires that the inventor know that the invention actually works for its intended purpose. ${ }^{22}$ Often that requires building and testing a model. Indeed, patent law early on developed a concept of experimental use that permitted those who had built a working prototype of the invention to test that invention to make sure it worked for its intended purpose without losing their right to a patent by doing so. ${ }^{23}$

But that view of invention has long coexisted with a second view, one that treats the mental act as the inventor's paramount contribution. While that view has roots going back to Robinson's famous 1890 patent treatise, ${ }^{24}$ its fullest expression came in the Supreme Court's

concurring) ("the patent system does not extend to all products of human ingenuity. Because the system's objective is to encourage 'the onward march of science,' O'Reilly v. Morse, 56 U.S. (15 How.) 62, 113 (1853), its rewards do not flow to ideas-even good ones-outside of the technological arena."). 21 Corona Cord, 276 U.S. at 382.

22 See, e.g., Estee Lauder Inc. v. L'Oreal S.A., 129 F.3d 588, 593 (Fed. Cir. 1997) (“in addition to preparing a composition, an inventor must establish that he knew it would work, to reduce the invention to practice.... [A] reduction to practice does not occur until an inventor, or perhaps his agent, knows that the invention will work for its intended purpose."). The Estee Lauder court held that an inventor who had sent a composition out for testing but had not yet received the successful test results did not yet know that the invention would work for its intended purpose and therefore had not yet actually reduced to practice.

${ }^{23}$ See, e.g., City of Elizabeth v. Pavement Co., 97 U.S. 126 (1877); Lough v. Brunswick Corp., 86 F.3d 1113, 1121 (Fed. Cir. 1996). Experimentation is permitted to stop the clock only until reduction to practice is complete; "experimental use can not occur after a reduction to practice." Continental Plastic Containers v. Owens Brockway Plastic Prods., 141 F.3d 1073, 1079 (Fed. Cir. 1998); Zacharin v. United States, 213 F.3d 1366, 1369 (Fed. Cir. 2000). Market testing to gauge consumer demand is not experimental use. In re Smith, 714 F.2d 1127, 1135 (Fed. Cir. 1983).

241 William Robinson, Robinson on Patents $\S 80$ (1890) ("To him alone whose mind conceives the perfect, practical, operative idea - that idea which, when embodied in tangible materials, will 
1998 decision in Pfaff. There, the court distinguished its nineteenth-century cases and

concluded that "[t]he primary meaning of the word 'invention' in the Patent Act unquestionably refers to the inventor's conception rather than to a physical embodiment of that idea." ${ }^{25}$ For courts and scholars that take this view, it is a new idea that represents the primary contribution of an invention. Various people can implement the idea once it is disclosed, but no one could do so without the mental act - the conception of the idea itself. On this view, implementation is less important. Indeed, one purpose of the patent system might be to permit people with ideas to sell those ideas to others who will test or implement them. ${ }^{26}$

Notably, conception of an invention does not require that the inventor know that the invention will work for its intended purpose. I can conceive of an invention without having any idea whether or not it will work in practice. Indeed, I may not even know what my invention is as long as I can make it and have some concept of an intended use. ${ }^{27}$ Figuring out whether it

accomplish the desired result - belongs the right of the inventor and the credit of performing the inventive act.").

25 Pfaff v. Wells Elecs., 525 U.S. 55, 66 (1998). See also Hybritech v. Monoclonal Antibodies, Inc., 802 F.2d 1367 (Fed. Cir. 1986).

26 See, e.g., Jonathan Barnett, Intellectual Property as a Law of Organization, 84 S. Cal. L. Rev. 875 (2011); Daniel Spulber, How Patents Provide the Foundation of the Market for Inventions, http://papers.ssrn.com/sol3/papers.cfm?abstract id=2487564 (2014).

27 See, e.g., Abbott Labs v. Geneva Pharms., Inc., 182 F.3d 1315 (Fed. Cir. 1999) (holding that a company that produced and sold a particular form of a chemical without knowing what it was had nonetheless reduced it to practice and therefore started the one-year clock running). Nicole Fortune argues that reduction to practice in $A b b o t t$ is an alternative to proof of conception as evidence that the invention was ready for patenting. Nicole M. Fortune, Scaltech Inc. v. Retech/Tetra LLC \& Abbott Laboratories v. Geneva Pharmaceuticals, Inc., 15 Berkeley Tech. L.J. 185 (2000). For discussion of the policies underlying the on sale bar, see William C. Rooklidge \& W. Gerald von Hoffman, III, Reduction to Practice, Experimental Use and the "On Sale" and "Public Use" Bars to Patentability, 63 St. John's L. Rev. 1 (1988).

In theory the utility doctrine could require more - proof of operability. See Robert Patrick Merges \& John Fitzgerald Duffy, Patent Law and Policy 255 ( $6^{\text {th }}$ ed. 2013) ("the utility doctrine is actually about timing ... If the utility requirement is relatively lax, then inventors can obtain a patent relatively early in their research."). In practice, however, the doctrine plays a very limited role in most industries. 
works often involves reduction to practice and experimentation. But conception requires

neither. While the definition of conception requires that the idea actually turn out to work, ${ }^{28}$ the inventor does not need to understand why it works or even know whether it will turn out to work for a particular purpose in order to have conceived of the invention. ${ }^{29}$ It is enough that the invention turns out to work. ${ }^{30}$

The 1952 Patent Act at first blush seems to strike a middle ground between these views. Section 102(g) of that Act provides that when two parties both claim to be the first inventor, the courts are to consider both the respective dates of conception and reduction to practice, as well as the diligence of someone who is first to conceive and last to reduce to practice. ${ }^{31}$ Thus, neither conception nor reduction to practice alone determines when someone has invented; invention occurs only once someone has conceived and is at least working diligently towards reduction to practice.

In fact, however, the reduction to practice section $102(\mathrm{~g})$ contemplates is not necessarily a real reduction to practice. The law permits the filing of an enabling patent

See Dan L. Burk \& Mark A. Lemley, Policy Levers in Patent Law, 89 Va. L. Rev. 1575 (2003) (noting that utility essentially never matters except in the life sciences). For an argument that a more robust utility doctrine could improve the patent system, see Michael J. Risch, Reinventing Usefulness, 2010 B.Y.U. L. Rev. 1195. But see Sean Seymore, Making Patents Useful, 98 Minn. L. Rev. 1046 (2014).

28 See, e.g., Dawson v. Dawson, 710 F.3d 1347, 1356 (Fed. Cir. 2013) (holding that conception requires a "definite and permanent idea of the complete and operative invention as it is hereafter to be applied in practice.") (emphasis added).

29 See, e.g., Burroughs Wellcome Co. v. Barr Labs, Inc., 40 F.3d 1223, 1228 (Fed. Cir. 1994) ("an inventor need not know that his invention will work for conception to be complete. He need only show that he had the idea; the discovery that an invention actually works is part of its reduction to practice.").

30 Dawson, 710 F.3d at 1356 ("part of the conception inquiry asks whether the inventor possessed an operative method of making the invention."); Invitrogen Corp. v. Clontech Labs., Inc., 429 F.3d 1052, 1063 (Fed.Cir. 2005) (same).

3135 U.S.C. $\S 102$ (g). 
application to serve as a "constructive" reduction to practice sufficient to count for priority purposes. ${ }^{32}$ That constructive reduction to practice is given parity with an actual reduction to practice. Put another way, the law of priority doesn't give any preference to inventors who actually build and test a device over those who merely write a patent application describing their conception. To the contrary: if you choose to constructively reduce the invention to practice you don't need to show that you know the invention will work for its intended purpose. $^{33}$ So in an important class of cases - inventions whose inventor has an idea but isn't yet sure if it will work - these "paper patentees" ${ }^{34}$ are more likely to win a priority contest than those who wait to build and test their invention before filing. ${ }^{35}$

To be sure, the patent application must be enabling: it must teach a person having ordinary skill in the art enough that they could make and use the invention without "undue experimentation.." ${ }^{36}$ But the courts have permitted applications that require a fair amount of

32 See, e.g., In re Lundak, 773 F.2d 1216 (Fed. Cir. 1985).

33 See, e.g., Robotic Vision Sys., Inc. v. View Eng'g, Inc., 249 F.3d 1307, 1312 (Fed. Cir. 2001) (holding an invention ready for patenting despite evidence "that one of the inventors expressed skepticism as to whether the invention would work for its intended purpose": "It will be a rare case indeed in which an inventor has no uncertainty concerning the workability of his invention before he has reduced it to practice. No such requirement will be applied here."). See also Pfaff v. Wells Elecs., 525 U.S. 55, 66 (1998), in which the Court held that an invention was ready for patenting before the patentee built it. By contrast, if the idea is so unformed that the patentee cannot describe it in an enabling way, it is not ready for patenting. Space Systems/Loral, Inc. v. Lockheed Martin Corp., 271 F.3d 1076, 1080 (Fed. Cir. 2001).

34 Mark A. Lemley, Ex Ante Versus Ex Post Justifications for Intellectual Property, 71 U. Chi. L. Rev. 129, 137(2004). For a discussion of paper patentees and their historic treatment in the law, see Duffy, supra note _.

35 It is hard to know precisely how often this happens. Colleen Chien and I found that a surprisingly large percentage of interference proceedings between competing claimants to the same invention were won by someone other than the first to file, but that in most cases it was the first to reduce to practice, not the first to conceive, that prevailed. Mark A. Lemley \& Colleen V. Chien, Are the U.S. Patent Priority Rules Really Necessary?, 54 Hastings L.J. 1299 (2003). The total number of cases is small, however.

36 See, e.g., In re Wands, 858 F.2d 731 (Fed. Cir. 1988). 
experimentation without invalidating a patent claim on enablement grounds. ${ }^{37}$ And part of that "due" experimentation can involve figuring out that the invention actually works. ${ }^{38}$ Courts have permitted applicants with an idea but no way to know whether that idea works to use "prophetic examples" - essentially, guesses as to what would happen if they were to build and test the invention. ${ }^{39}$ If that guess turns out to be reasonably accurate, the paper patentee gets credit for teaching others how to make and use the invention even though she never did so herself. $^{40}$

The result is to disadvantage inventors who actually build and test their inventions before filing a patent application. An inventor is better off filing a patent application as early as possible, before - or perhaps instead of - building a prototype or testing the invention. An inventor who waits to build and test a prototype can qualify as the first inventor even if someone else files an application first, but only if they can show that they were diligent in reducing the invention to practice. The test for diligence is quite strict, requiring continuous

37 See id. The cases center on whether experimentation is "undue." A patent is not enabling if excessive experimentation is required. Wyeth v. Abbott, 720 F.3d 1380 (Fed. Cir. 2013). There is some reason to think the court is tightening up the enablement requirement, particularly when it comes to overbroad claims. See, e.g., Timothy Holbrook, Patents, Presumptions, and Public Notice, 86 Ind. L.J. 779 (2011); Sean Seymore, The Enablement Pendulum Swings Back, 6 Nw. J. Tech. \& Intell. Prop. 278 (2008).

38 Robotic Vision, 249 F.3d at 1312; Burroughs Wellcome, 40 F.3d at 1228.

39 See, e.g., Atlas Powder v. E.I. du Pont de Nemours, 750 F.2d 1569 (Fed. Cir. 1984).

40 Of course, it is always possible that such a prophecy will turn out to be wrong - that the invention won't work as predicted. But if so, the patent will generally not turn out to be particularly valuable whether or not it was tested first. Indeed, such a patent should be invalid for lack of utility as well as lack of enablement.

For a discussion of prophetic examples and their problems, see, e.g., Sean Seymore, Heightened Enablement in the Unpredictable Arts, 56 UCLA L. Rev. 127 (2008). 
acts to build and test the invention. ${ }^{41}$ Inventors have lost their claim because they spent even a week or two doing something other than building the invention. So diligence is unlikely to provide much of a counterweight. ${ }^{42}$ As against the inventor who went straight to the patent office, those who seek to build and test the invention are at a disadvantage.

Those who actually build a prototype are disadvantaged in a second way under the 1952 Act. The "on sale" bar applies to those who sell the actual physical embodiment of the invention, but not to those who sell or license the idea of the invention itself. ${ }^{43}$ The Supreme $^{2}$ Court expanded the doctrine somewhat to include those who put the invention on sale before they have actually built a prototype, but even then it is only selling the working invention itself, not selling the idea for the invention, that can trigger the one-year bar date for patenting. ${ }^{44}$ There are decent reasons not to force those who are seeking to sell an idea to obtain a patent before they know whether the idea is worth anything. ${ }^{45}$ But the fact remains that if you sell an idea committed to paper alone, the law will treat you more favorably than if you sell a prototype along with your idea.

41 See, e.g., Griffith v. Kanamaru, 816 F.2d 624 (Fed. Cir. 1987).

42 Colleen Chien and I have found that only $10 \%$ of interference cases are decided on diligence grounds, and of those only $2.5 \%$ found for the junior filer based on their diligence in reducing to practice. Mark A. Lemley \& Colleen V. Chien, Are the U.S. Patent Priority Rules Really Necessary?, 54 Hastings L.J. 1299, tbl. 2 (2003).

43 See, e.g., Minton v. Nat'l Ass'n of Securities Dealers, 336 F.3d 1373 (Fed. Cir. 2003) (transfer of knowhow of a claimed process is not a sale under 102(b), but transfer of an operational computer program that performs the claimed process is); In re Kollar, 286 F.3d 1326 (Fed. Cir. 2002) (same).

44 Pfaff v. Wells Elecs., 525 U.S. 55, 66 (1998).

45 For discussion of these issues, see, e.g., Timothy R. Holbrook, The More Things Change, the More They Stay the Same: Implications of Pfaff $v$. Wells Electronics, Inc. and the Quest for Predictability in the On-Sale Bar, 15 Berkeley Tech. L.J. 933 (2000). 


\section{The AIA and the Move Away From Construction and Testing}

The 1952 Act, then, put a thumb on the scale in favor of filing a patent application early rather than waiting to build something. In 2011, Congress enacted the America Invents Act (AIA), the most substantial overhaul of the patent system in the past sixty years. The AIA does even more than the 1952 Act to encourage early filing.

The most significant change in the AIA was the move from a first to invent regime to a first inventor to file regime. Before 2011, U.S. patent law chose among competing claimants to a patent by favoring the first to invent. Under the AIA, we (largely) follow the rest of the world in awarding the patent to the first inventor to file a patent application. ${ }^{46}$ The goal of the move to (mostly) first to file, besides harmonization, is to encourage inventors to move with alacrity to share their invention with the world. ${ }^{47}$ Under the new law, an inventor can't rest on merely having invented; they have to race to the Patent and Trademark Office (PTO) in hopes of beating competitors. Whether it is by filing a (later-published) patent application or by publishing the invention, one of the touted advantages of the AIA is that it will encourage inventors to promptly disclose their ideas to the public. ${ }^{48}$ And the means of that disclosure is ultimately keyed to the filing of the patent application, not to releasing a product.

The structure of the AIA is not encouraging to those who would build and test their

46 Portions of this paragraph and the one that follows are adapted from Mark A. Lemley, Does Public Use Mean the Same Thing It Did Last Year?, _ Tex. L. Rev. _ (forthcoming 2015).

47 For an empirical analysis of the likely effects of the move, see David S. Abrams \& R. Polk Wagner, Poisoning the Next Apple? The America Invents Act and Individual Inventors, 65 Stan. L. Rev. 517 (2013).

48. See, e.g., White House Office of the Press Secretary, President Obama Signs America Invents Act, Overhauling the Patent System to Stimulate Economic Growth, and Announces New Steps to Help Entrepreneurs Create Jobs (Sept. 16, 2011) (noting that the purpose of the bill was to help inventors bring their ideas to market more quickly). 
invention before filing a patent application. As we have seen, the 1952 Act gave a patent to the first person to invent, and invention was defined as a hybrid between conception and (actual or constructive) reduction to practice. I argued in the last section that that hybrid approach was insufficiently protective of those who chose to build rather than simply patent. But the AIA replaces the first-to-invent system with a first-to-file priority system. While a first-to-file system has the advantage of simplicity, eliminating many of the complex rules for priority under the 1952 Act, $^{49}$ it also eliminates any ability for an inventor who waits to file her patent application until after she has perfected the invention to claim priority against a paper patentee who heads straight to the patent office. No matter who invented first or how good the argument for delaying in order to build and test the invention, under the AIA the inventor who arrives at the patent office second loses. ${ }^{50}$ Put another way, while the 1952 Act didn't give enough encouragement to build and test, the AIA gives none at all.

The AIA may make it more difficult to build and test the invention in another way. There is one doctrine in the pre-AIA case law that encourages inventors to build and test their inventions before filing for a patent. That is the experimental use doctrine. The 1952 Act requires that an inventor file a patent application within one year after engaging in a public use or a sale of the invention. The experimental use doctrine stops the clock running if the inventor can show that her sale or public use was part of an effort to experiment on the invention,

49 See Lemley \& Chien, supra note _ (discussing the simplicity advantages of a first-to-file rule); Gerald J. Mossinghoff, The U.S. First-to-Invent System has Provided No Advantage to Small Entities, 88 J. PAT. \& TRADEMARK OFC. SOC'Y 425, 425 n.1 (2002).

5035 U.S.C. $\$ 102(a)(2)$. There is a limited exception for those who publicly disclose their invention before anyone else applies for a patent, which I discuss below. 
reducing it to practice and making sure it works for its intended purpose. ${ }^{51}$ While patent law normally bars a patent if the invention has been on sale or in public use for more than a year, the experimental use defense allows an inventor to extend that period by selling or using her invention herself for more than a year for purposes of experiment. ${ }^{52}$ But only the inventor's uses or those she licenses are excused; a third party's sale or public use of the same invention will start the one-year clock running.

Does experimental use survive the AIA? The new statutory framework suggests that what I do between conception and reduction to practice doesn't matter, but also won't prevent another inventor from patenting first. My own public disclosures in printed publications will bar others from getting a patent if they didn't file or disclose first. They will preserve my right to later file for a patent, but only for a year. My own sales and uses of the invention will not bar me from getting a patent, but only for a year. One question is whether those one-year bar dates get extended by proof of experimental use. I have argued elsewhere that the experimental use doctrine should survive into the AIA, allowing inventors who are engaged in

51 See, e.g., Pfaff v. Wells Elecs., 525 U.S. 55, 64 (1998) ("an inventor who seeks to perfect his discovery may conduct extensive testing without losing his right to obtain a patent . . . even if such testing occurs in the public eye."). There is a fact-specific, multifactor test to determine whether a particular use or sale is in fact an experiment. See, e.g., Baker Oil Tools, Inc. v. Geo Vann, Inc., 828 F.2d 1558, 1564 (Fed. Cir. 1987); Monon Corp. v. Stoughton Trailers, Inc., 239 F.3d 1253 (Fed. Cir. 2001); Lough v. Brunswick Corp., 86 F.3d 1113, 1121 (Fed. Cir. 1996). For a detailed discussion of the multi-factor test, see, e.g., Shashank Upadhye, To Use or Not to Use: Reforming Patent Infringement, the Public Use Bar, and the Experimental Use Doctrine as Applied to Clinical Testing of Pharmaceutical and Medical Device Innovation, 4 Minn. Intell. Prop. Rev. 1, 12-50 (2002). The Federal Circuit has sometimes spoken of the experimental use doctrine as simply part of the public use inquiry, see TP Labs., Inc. v. Professional Positioners, Inc., 724 F.2d 965, 971 (Fed. Cir. 1984), but it has done so in order to align the burden of proof. The two questions are analytically distinct. One asks whether a use was reasonably accessible to the public; the other asks whether that use should nonetheless not trigger the one-year clock because it was done for experimental purposes. Not all experiments are public, and not all public uses are experiments.

52 City of Elizabeth v. Pavement Co., 97 U.S. 126 (1877). 
experimentation to sell or use their inventions in public for more than a year without barring themselves from later getting a patent. ${ }^{53}$ But others have argued that the term "public use" should be reinterpreted anew even though it was carried over from the old statute, and that the new "public use" language should not incorporate the common law interpretations of the old "public use." ${ }^{54}$ The Patent and Trademark Office originally took a position of neutrality, suggesting it is an open question whether the experimental use doctrine survives into the AIA, but now seems to think experimental use does not survive at all. ${ }^{55}$ Without an experimental use exemption, inventors who actually build and test their inventions will be at a substantial disadvantage if deploying and testing requires the participation of outsiders, as is often the case in software and a variety of inventions intended for widespread public use.

Even if the experimental use doctrine survives into the AIA, it may offer less protection to implementers than it once did. The AIA continues the one-year grace period to file an application present in the 1952 Act. But the structure of the grace period is different. The

53 Lemley, Public Use, supra note _.

54 See, e.g., Joe Matal, A Guide to the Legislative History of the America Invents Act, Part I of II, 21 Fed. Cir. B.J. 435, 466-74 (2012) (arguing that the AIA excluded secret commercial uses, based largely on Senator Kyl's statements on the Senate floor); Robert A. Armitage, Understanding the America Invents Act and Its Implications for Patenting, 40 AIPLA Q.J. 1, 51-60 (2012).

55 The U.S. Patent and Trademark Office released comments regarding examination under AIA. See 78 Fed.Reg. 11059 (2013). Comment 12 addresses the issue of the experimental use exception to public use, and whether the exception remains viable under the AIA. According to the PTO, "[u]nder pre-AIA case law, the experimental use exception negates a use that would otherwise defeat patentability. Neither the AIA nor its legislative history expressly addresses whether the experimental use exception applies to a public use under AIA 35 U.S.C. 102(a)(1), or to a use that makes the invention available to the public under the residual clause of AIA 35 U.S.C. 102(a)(1). Because this doctrine arises infrequently before the [PTO], and is case-specific when it does arise, the [PTO] will approach this issue when it arises on the facts presented." Id. at 11063. The PTO's Manual of Patent Examining Procedure, by contrast, now instructs examiners not to apply the experimental use doctrine. MPEP §2133.03(3) ("This MPEP section is not applicable to applications subject to examination under the first inventor to file (FITF) provisions of the AIA.") (emphasis in original). 
grace period in the 1952 Act was absolute: no conduct by any party after an inventor had invented could bar that inventor from getting a patent within a year after a public disclosure, sale, or use. And the experimental use doctrine allowed the patentee to extend that one year grace period for their own sales and uses, though not sales or uses by unrelated third parties. ${ }^{56}$ By contrast, the absolute one-year grace period under the AIA does not apply to all disclosures, but only to the subset of "public disclosures." Section 102(b) reads:

(b) EXCEPTIONS.--

(1) DISCLOSURES MADE 1 YEAR OR LESS BEFORE THE EFFECTIVE FILING DATE OF THE CLAIMED INVENTION.--A disclosure made 1 year or less before the effective filing date of a claimed invention shall not be prior art to the claimed invention under subsection (a)(1) if--

(A) the disclosure was made by the inventor or joint inventor or by another who obtained the subject matter disclosed directly or indirectly from the inventor or a joint inventor; or

(B) the subject matter disclosed had, before such disclosure, been publicly disclosed by the inventor or a joint inventor or another who obtained the subject matter disclosed directly or indirectly from the inventor or a joint inventor. $^{57}$

Thus, while under the 1952 Act a third party's conduct within the one-year grace period could not bar an inventor from getting a patent, that is no longer true. If the inventor "discloses" but

56 See, e.g., Eolas Techs. Inc. v. Microsoft Corp., 399 F.3d 1325, 1334 (Fed. Cir. 2005) ("Third party prior use accessible to the public is a section 102(b) bar."). While one inventor can avoid a bar by showing that her sale or public use was experimental, that same sale will start the clock running for everyone else, even if the use was not practically accessible to anyone else. See Baxter Int'l v. COBE Labs., Inc., 88 F.3d 1054 (Fed. Cir. 1996). But cf. Delano Farms Co. v. California Table Grape Comm'n, _ F.3d__ (Fed. Cir. Jan. 9, 2015) (holding that two farmers who grew the patentee's grapes without permission did not create a public use because they were bound to an implied confidentiality agreement). The result is a potential paradox: if two independent inventors both experiment on the invention the same time in an effort to reduce it to practice, each one's experimental public use will bar the other from getting a patent.

5735 U.S.C. §102(b) (emphasis added). 
does not "publicly disclose" the invention, independent disclosures by a third party even after that disclosure can still bar her patent. For instance, if an inventor makes a few non-public sales of the invention to beta-testers, those sales will not themselves bar her from filing a patent for a year, and perhaps longer if they are part of a bona fide experimental use. But independent sales or uses by a third party during that year will bar her from obtaining a patent even if she was engaged in experimentation. ${ }^{58}$

I have written elsewhere on the uncertainty over what constitutes a disclosure but not a "public disclosure" under the AIA. ${ }^{59}$ However that debate is resolved, some things - most likely noncommercial uses of the invention and non-public sales - will count as prior art that triggers the provisions of the AIA but will not count as a public disclosure sufficient to trigger the absolute protection of the one-year grace period. And those very things - secret, noncommercial uses and non-public sales to a few buyers - are the very sorts of activities that are most likely to be consistent with true experimentation. An inventor who builds and wants to test her invention will need to use it, and perhaps enlist others to use it, to be sure that it works for its intended purpose. But in doing so, she may unwittingly open the door to third party conduct that will prevent her from getting a patent once she determines that the invention does work. They could, perhaps, make a public disclosure of the experiment while it was going on, hedging against the risk that someone else will beat them to the patent office. But even that will only buy them a year in which to experiment.

58 By contrast, if the third party got the idea from our inventor, that party's conduct cannot bar a patent during the one-year grace period. 35 U.S.C. $\$ 102(b)(1)(A)$.

59 Lemley, Public Use, supra note _. See also Robert P. Merges, Property and Novelty Under the AIA, 27 Berkeley Tech. L.J. 1023 (2012). 
Patent law, then, has always put a thumb on the scale in favor of patenting first and figuring out only later if the invention will actually work. But with the AIA, that thumb has become a fist, weighing heavily against actually building and testing an invention before heading to the Patent Office.

\section{Towards (Some) Parity for Builders}

\section{A. The Problem with Early Filing}

I think favoring early filing over actually building and testing the invention is probably a

mistake. Chris Cotropia has explained well what he calls the "folly of early filing" of patents:

Filing early and often exacerbates many of the patent system's most recognized problems. It adds significantly to the ever-rising number of applications, contributing to the backlog and burden on the United States Patent and Trademark Office (USPTO) that reduces the quality of examination and issued patents. More applications means more issued patents, which cause problems of their own, particularly if they are "bad" patents. The earlier patents are filed, the more likely they go undeveloped. Commercialization does not occur because of the great uncertainty and the minimal investment at the time of filing. Asserting an early-filed patent is a cheaper alternative to commercialization. This low-cost option entices patent trolls who use patents solely to extract rents from those engaged in commercial development. The dearth of information and the great uncertainty at the time of filing also contributes to the lack of clarity in the patent's specification and claims, causing patent boundaries to be unclear. ${ }^{60}$

Cotropia makes a strong case.

True, there are some advantages to society from early filing. A patent application that is filed earlier will, all other things being equal, result in a patent that expires earlier, releasing the invention to the public domain. ${ }^{61}$ And as I have observed elsewhere, we don't want inventors

60 Cotropia, supra note _, at 70.

61 John F. Duffy, Rethinking the Prospect Theory of Patents, 71 U. Chi. L. Rev. 439, 440 (2004). Since 1995, patents normally expire twenty years after the filing date. 35 U.S.C. $\S 154$. But that term can be 
to deliberately delay filing (and hence expiration) while taking commercial advantage of the invention. $^{62}$

Other purported advantages turn out to be illusory, however. While patent law may encourage racing to a new invention, as I have argued, ${ }^{63}$ that begs the question of to what end inventors are racing. We might be better off having inventors race to build something than simply race to come up with new ideas first. Patent disclosure theory is premised on the idea that the patent document teaches the world how to make and use the invention. In fact, however, patents rarely provide much in the way of useful scientific knowledge in most industries; ${ }^{64}$ scientists who are doing research tend to look elsewhere than patents for their learning. ${ }^{65}$ And that is likely to be even more true of patents filed by those who never made a product, since those patents will lack the level of technical detail and experimental results that an inventor who has actually constructed and tested a prototype can offer.

extended for a variety of reasons. Id. $\$ 154(b)$. Even before 1995, when patents lasted 17 years from the date of issue, early filing normally meant earlier issuance and therefore earlier expiration.

62 Lemley, Public Use, supra note _, at _..

63 Lemley, Myths, supra note __, at 749-57.

64 Id. At 744-48 (collecting sources); Alan Devlin, The Misunderstood Function of Disclosure in Patent Law, 23 Harv. J.L. \& Tech. 401, 403 (2010); Note, The Disclosure Function of the Patent System (or Lack Thereof), 118 Harv. L. Rev. 2007, 2025-26 (2005); Jeanne C. Fromer, Patent Disclosure, 94 lowa L. Rev. 539, 542 (2009).

65 I often ask the former scientists and engineers in my patent class whether they ever read patents as a way of doing scientific background reading; the question provokes a chorus of denials and generally giggles at the very idea.

That said, the value of patents as disclosure tools may differ from industry to industry, and some types of scientists may read patents, as Lisa Ouellette has suggested. Lisa Larrimore Ouellette, Do Patents Disclose Useful Information?, 25 Harv. J.L. \& Tech. (2012). See also John M. Golden, Principles for Patent Remedies, 88 Tex. L. Rev. 505, 522 (2010). Patents may also encourage the sort of disclosures that do communicate information, for example by giving scientists at companies the comfort necessary to present their work at conferences. For a discussion of this sort of indirect learning, see Mark A. Lemley, The Myth of the Sole Inventor, 110 Mich. L. Rev. 709 (2012). 
Further, there is often a wide gap between the knowledge produced by having an idea and the knowledge produced by getting that idea to work. There is a substantial economic literature on "learning by doing" that suggests much knowledge about an invention is tacit, and is acquired by actually making something work, not merely by thinking about it in the abstract. ${ }^{66}$ That richness of knowledge means that those who actually design and test an invention can disclose more detail about it (in patent applications and elsewhere) than those who think of an idea and then stop. In some fields, the only way to know whether something will work is to try it. But even in other, more predictable fields, there is often a long series of steps between having an idea and having a design that will work. Thus, even if we think manufacturing will increasingly become automated, there is substantial inventive value to building and testing prototypes, or at least putting together working designs in CAD files. It is the difference between having the idea to 3D-print a rocket engine and actually producing a design specification for doing so. Both are information, but the latter is more useful than the former. And yet current law would not only give a patent to the former, but would be inclined to give a broader patent to the inventor who just came up with the idea than to the one who actually figured out a working implementation of that idea.

\section{B. Should We Eliminate Paper Patents?}

66 Kenneth J. Arrow, The Economic Implications of Learning by Doing, 29 Rev. Econ. Stud. 155, 155 (1962); Eytan Sheshinski, Tests of the "Learning by Doing" Hypothesis, 49 Rev. Econ. \& Stat. 568, 568 (1967); Michael Polanyi, The Tacit Dimension 4 (1966). For a discussion in the patent context, see Duffy, Paper Patents, supra note _, at 1389-96. 
Cotropia would restore parity between those who build the invention and those who do not by the simple expedient of barring the latter from getting a patent. ${ }^{67}$ While he would not go as far as those who would require commercialization of the invention, ${ }^{68}$ he would require proof of actual, not constructive, reduction to practice before filing a patent application. ${ }^{69}$ For Cotropia, as for Justice Story, it is the delivery of a working product, or at least a prototype, that is the thing worthy of patent protection. ${ }^{70}$

I have some sympathy for Cotropia's position, and I think we need to do more to encourage - or at least not disadvantage - those who chose to build and test a prototype. But requiring actual reduction to practice probably goes too far. In some fields, such as semiconductors, designers may not be able to actually build and test their inventions without a great deal of time and money - money that inventors may not be able to pay. Patents have allowed vertical disintegration in that industry, permitting independent design firms to produce and sell designs to semiconductor manufacturers. ${ }^{71}$ Other inventors, particularly those

67 Id. at 71.

68 See, e.g., Posner, supra note __; Yosick, supra note __; Maayan Perel, From Non-Practicing Entities (NPEs) to Non-Practiced Patents (NPPs): A Proposal for a Patent Working Requirement, _ U. Cin. L. Rev. _ (forthcoming 2015), available at http://papers.ssrn.com/sol3/papers.cfm?abstract_id=2496281. Cf.

Ted Sichelman, Commercializing Patents, 62 Stan. L. Rev. 341 (2010) (arguing, not for a commercialization requirement for patentability, but for separate patents to encourage commercialization). Importantly, Sichelman's commercialization patent would vest in the company that commercialized the invention, not the person who invented but did not commercialize it.

69 Cotropia, supra note _, at _.

70 Id. at 128 ("The basic goal of the patent system is the production of socially beneficial technology. That is, technology that society can actually use.").

71 See, e.g.., Bronwyn H. Hall \& Rosemarie Ziedonis, The Patent Paradox Revisited: An Empirical Study of Patenting in the U.S. Semiconductor Industry, 1979-1995, 32 RAND J. Econ. 101 (2001) (finding that strong patents in the semiconductor industry support the creation of design firms vertically disintegrated from manufacturing); Bronwyn $\mathrm{H}$. Hall \& Rosemarie Ziedonis, The Effect of Strengthening Patent Rights on Firms Engaged in Cumulative Innovation: Evidence from the Semiconductor Industry, http://citeseerx.ist.psu.edu/viewdoc/download?doi=10.1.1.24.6269\&rep=rep1\&type=pdf; Jonathan M. 
associated with universities, may not be well-positioned to build and test their inventions,

preferring instead to partner with an outside firm to do the development. ${ }^{72}$ And patents can sometimes facilitate that process of technology transfer. ${ }^{73}$ And even if the record of patents actually driving rather than following technology transfer is a mixed one, it would surely be desirable to move towards a patent system in which people with good ideas could sell those

Barnett, Property as Process: How Innovation Markets Select Innovation Regimes, 119 Yale L.J. 384 (2009); Barnett, supra note

72 For a discussion of university patenting and technology transfer, see, e.g., David Mowery et al., Ivory Tower \& Industrial Innovation: University-Industry Technology Transfer Before and After the BayhDole Act (2015); Mark A. Lemley, Are Universities Patent Trolls?, 18 Fordham Intell. Prop., Med., \& Ent. L.J. 611 (2008).

73 Arrow's Information Paradox posits that without some form of property right parties will find it difficult to contract for the sale of information. Kenneth J. Arrow, Economic Welfare and the Allocation of Resources for Invention, in The Rate and Direction of Inventive Activity 609, 620 (Nat'l Bureau of Econ. Research ed., 1962), reprinted in 5 Collected Papers of Kenneth J. Arrow 104, 115-17 (1985). There is substantial literature on patents as a way out of Arrow's paradox. See, e.g., James J. Anton \& Dennis A. Yao, Expropriation and Inventions: Appropriable Rents in the Absence of Property Rights, 84 Am. Econ. Rev. 190, 190-92 (1994); Paul J. Heald, Transaction Costs and Patent Reform, 23 Santa Clara Computer \& High Tech. L.J. 447, 453-54 (2007); Robert P. Merges, A Transactional View of Property Rights, 20 Berkeley Tech. L.J. 1477 (2005); Robert P. Merges, Intellectual Property and the Costs of Commercial Exchange: A Review Essay, 93 Mich. L. Rev. 1570, 1590 (1995) (noting the importance of contract law in intellectual property exchanges). Cf. Mark A. Lemley, The Surprising Virtues of Treating Trade Secrets as Intellectual Property Rights, 61 Stan. L. Rev. 311 (2008) (arguing that trade secrets can serve the same purpose without patents). But see Michael J. Burstein, Exchanging Information Without Intellectual Property, 91 Tex. L. Rev. 227 (2012) (arguing that we don't need patents to solve Arrow's Information Paradox, because structured disclosure of information and various other appropriability mechanisms can enable contracting).

By contrast, efforts to license the patent itself rather than the underlying ideas rarely seem to drive technology transfer. See Robin C. Feldman \& Mark A. Lemley, Does Patent Licensing Drive Innovation?, 101 lowa L. Rev. _ (forthcoming 2015) (surveying those involved in patent licensing and finding that efforts to license patents themselves rarely led to technology transfer or innovation, even from universities).

Cotropia suggests that inventors might file an application early but defer examination until they succeed in reducing the invention to practice. Cotropia, supra note _, at _. In so doing, he hopes to solve Arrow's Information Paradox by providing an inchoate right to contract over while conditioning the actual patent grant on successful completion of the reduction to practice. While it is an admirable effort, I'm not sure it will provide much more certainty than the trade secret rights that can already allow contracting for ideas. Lemley, supra; Burstein, supra. And it will create a host of new problems, from delaying the issuance of patents to reopening the question of who has invented a patent conceived by one company but reduced to practice by another. 
ideas to companies who could make use of them. ${ }^{74}$ Requiring everyone to build their own products would be a step away from that idea.

Further, while Cotropia is right that those who do not develop and test their invention are less likely to see it commercialized and more likely to become patent trolls, ${ }^{75}$ there are plenty of examples of product-producing companies who ultimately become trolls or sell their patents to trolls. ${ }^{76}$ The troll problem is more systemic than just allowing patents on ideas that never made it to fruition, ${ }^{77}$ though Cotropia is surely right that that is part of the problem.

Finally, and most practically, even if it were a good idea to require reduction to practice it is unlikely to happen. The AIA represents a significant step in the opposite direction, toward encouraging early filing divorced from commercialization or actual reduction to practice. ${ }^{78}$ Congress took that step in part in an effort to harmonize U.S. law with the rest of the world, which does not have such a requirement. ${ }^{79}$ Universities, which have had an outsized influence

74 Mark A. Lemley \& Nathan Myhrvold, How to Make a Patent Market, 36 Hofstra L. Rev. 257 (2007).

75 Cotropia, supra note _, at _.

76 Mark A. Lemley \& A. Douglas Melamed, Missing the Forest for the Trolls, 113 Colum. L. Rev. 2117 (2013); Tom Ewing, Indirect Exploitation of Intellectual Property Rights by Corporations and Investors, Hastings Sci. \& Tech. L.J., Winter 2012, at 1, 5 (defining IP privateering)..

77 Lemley \& Melamed, supra note _; cf. Brian J. Love, An Empirical Study of Patent Assertion Timing: Could a Patent Term Reduction Decimate Trolls Without Harming Innovators?, 161 U. Pa. L. Rev. 1309 (2013) (finding that patent trolls overwhelmingly assert patents at the end of their life, while productproducing companies assert patents earlier).

78 Lemley, Public Use, supra note _, at _; See, e.g., Press Release, The White House Office of the Press $\operatorname{Sec}^{\prime} y$, President Obama Signs America Invents Act, Overhauling the Patent System to Stimulate Economic Growth, and Announces New Steps to Help Entrepreneurs Create Jobs (Sept. 16, 2011), available at http://www.whitehouse.gov/the-press-office/2011/09/16/president-obama-signs-americainvents-act-overhauling-patent-system-stim, archived at http://perma.cc/V9WE-VQ4C (noting that the purpose of the bill was to help inventors bring their ideas to market more quickly); cf. Abrams \& Wagner, supra note _ (finding that a move to first to file may discourage individual inventors from filing because of concerns about a race to the PTO).

Lemley, Public Use, supra note _, at _.. 
on the terms of the patent reform debate, would doubtless resist such a move. ${ }^{80}$ And technology is moving away from integrated design and construction toward computer prototyping, making information, not physical production, increasingly important. The rise of 3D printing will make that separation even more acute. ${ }^{81}$ It seems implausible that the law will buck that trend and require that inventors produce and test their own inventions.

\section{A Middle Ground?}

If we are not to do away with constructive reduction to practice, we still need to confront the problems it creates. One way to do so would be to raise the bar to obtaining such a paper patent. We could, for instance, impose a stricter test for disclosing the invention to the world on inventors who cannot point to working examples - perhaps requiring them to explain the principle behind the invention if they are not going to prove that it works in practice. ${ }^{82}$ To some extent the law has been doing this already. The development and extension of the written description doctrine is in part directed at a practice I have called "gun jumping": rushing

80 One can find a number of examples of university influence in the AIA, from the exemption from prior user rights for university patents, 35 U.S.C. $\$ 273(e)(5)$, to the definition of a university as a "microentity" that got to pay lower fees even than individual inventors and other non-profits. 35 U.S.C. $\S 123(d)$. Senator Dianne Feinstein (D-Cal) stated at a hearing on the AIA that there were a number of great universities in California and she would vote to do what was in their interest, notwithstanding the prevalence of many great IT and biotech companies in California as well.

81 For discussions of the IP implications of 3D printing, see, e.g., Mark A. Lemley, IP in a World WithoutScarcity, 80 N.Y.U. L. Rev. (forthcoming 2015); Deven R. Desai \& Gerard N. Magliocca, Patents, Meet Napster: 3D Printing and the Digitization of Things, 102 Geo. L.J. 1291 (2014); Lucas S. Osborn, Of PhDs, Pirates, and the Public: Three-Dimensional Printing Technology and the Arts, 1 Texas A\&M L. Rev. 811 (2014); Lucas S. Osborn, Regulating Three-dimensional Printing: The Converging Worlds of Bits and Atoms, 51 San Diego L. Rev. 553 (2014); Timothy R. Holbrook \& Lucas S. Osborn, Digital Patent Infringement in an Era of 3D Printing, __ U.C. Davis L. Rev. _ (forthcoming 2015).

82 I thank Josh Sarnoff for this suggestion. 
to the Patent Office before actually spelling out what the invention actually is. ${ }^{83}$ Cases like Ariad v. Eli Lilly \& Co. and University of Rochester v. G.D. Searle \& Co., for instance, involve "inventors" who identified a fruitful area of research but did not actually hypothesize, much less construct, a product. They merely sought to lock up the results of research later done by someone else. ${ }^{84}$ Strengthening the enablement and written description requirements won't make paper patenting impossible, but it will nudge inventors toward building and testing their invention first by making it harder to get a patent without doing so. ${ }^{85}$ And while we don't want to encourage patent owners to delay too long in filing their applications, ${ }^{86}$ we may worry that patents that issue too early with too little information will not be sufficiently developed. ${ }^{87}$

Strengthening the disclosure doctrines will also tend to narrow the scope of the patents that do issue. One concern with early filing is that the very inventors who do not build something will draft the broadest claims, simply because they don't actually know what particular implementations of their idea will work. Meanwhile, those who actually do the work

83 See Mark A. Lemley et al., Life After Bilski, 63 Stan. L. Rev. 1315, _ (2011) (noting the prevention of gun jumping as one of the goals of 35 U.S.C. $\$ 112(a))$.

84 Ariad Pharms. v. Eli Lilly \& Co., 598 F.3d 1336 (Fed. Cir. 2010) (en banc); University of Rochester v. G.D. Searle \& Co., 358 F.3d 916 (Fed. Cir. 2004).

85 Interestingly, nearly a century ago courts relied on the "paper patent" doctrine to invalidate or limit the scope of patents in a number of cases in which the patentee had not actually built anything. They did so in language strikingly reminiscent of today's debate over patent trolls. See, e.g., Van Kannel Revolving Door Co. v. General Bronze Corp., 77 F.2d 300, 303 (2d Cir. 1935) (rejecting a suit on an "inoperative paper patent which had no effect on the art and was only brought to light by the plaintiff in an effort to monopolize the field after the defendant had already installed, to the plaintiff's knowledge, a governor of the type now charged to infringe."). For a discussion of the use of the paper patent doctrine, and the ways in which it could benefit as well as harm patentees, see Duffy, supra note __, at 1374-82.

86 Duffy, Prospect Theory, supra note _.

87 See, e.g., Sichelman, supra note _, at 393-95; Michael Abramowicz, The Danger of Underdeveloped Patent Prospects, 92 Cornell L. Rev. 1065 (2007). 
may write more specific - and therefore narrower - claims. A particular example of this problem is functional claiming - claiming to own any technology that solves a particular problem, rather than the particular solution the patentee came up with. ${ }^{88}$ Functional claiming is endemic in software patents, and is arguably responsible for many of the problems with patenting software. ${ }^{89}$ And many of those claims are from patentees who never actually implemented their ideas. While the law properly refuses to limit inventors to the particular embodiments they design, functional claiming goes to the opposite extreme, attempting to lay claim to an entire problem without offering a particular solution. I have argued elsewhere that these functional claims are properly understood as covering, not every possible way of solving the problem, but only the ways the patentee actually described in her specification. ${ }^{90} \mathrm{~A}$ functional claim that is backed up with specific examples is valid but narrowed to those examples and equivalents thereof. ${ }^{91}$ A functional claim that is not backed up with specific examples is invalid as indefinite. ${ }^{92}$ Taking that approach may also encourage inventors to

88 See Mark A. Lemley, Software Patents and the Return of Functional Claiming, 2013 Wis. L. Rev. 905.

89 Id. at _ . Functional claiming is not limited to software, however. For criticism of functional claiming in biotechnology, see Abbvie Deutschland GMBH \& Co. v. Janssen Biotech, Inc., 759 F.3d 1285 (Fed. Cir. 2014).

90 Id. at _.

9135 U.S.C. §112(f).

92 Function Media, LLC v. Google Inc., 708 F.3d 1310, 1318 (Fed. Cir. 2013); ePlus, Inc. v. Lawson Software, Inc., 700 F.3d 509, 518-19 (Fed. Cir. 2012); Noah Sys., Inc. v. Intuit Inc., 675 F.3d 1302, 1312-13 (Fed. Cir. 2012); Ergo Licensing, LLC v. CareFusion 303, Inc., 673 F.3d 1361, 1362, 1365 (Fed. Cir. 2012); Typhoon Touch Techs., Inc. v. Dell, Inc., 659 F.3d 1376, 1384-86 (Fed. Cir. 2011) (means-plusfunction software claims required disclosure of corresponding structure performing that function in the specification, but that structure did not need to be described in the form of software code); In re Aoyama, 656 F.3d 1293, 1294, 1297-98 (Fed. Cir. 2011) (means-plus-function software patent claim invalid as indefinite for failure to disclose the corresponding algorithm performing that function); Aristocrat Techs. Austl. PTY Ltd. v. Int'I Game Tech., 521 F.3d 1328, 1337-38 (Fed. Cir. 2008); WMS Gaming, Inc. v. Int'I Game Tech., 184 F.3d 1339, 1349 (Fed. Cir. 1999) (“[T]he disclosed structure is not the general purpose computer, but rather the special purpose computer programmed to 
affirmatively build their invention to provide those examples. At the very least, a paper patentee that gives only "prophetic examples" will be limited to those examples and not entitled to lay claim to whatever solutions actually turn out to work. And precisely because the paper patentee has done no testing, those examples may not turn out as prophetic as the inventor imagines. ${ }^{93}$

A final solution involves offering some protection to inventors choose to build and test against others who run to the patent office instead. As we saw in Part I, the 1952 Act offered (incomplete) protection to builders by allowing the first inventor to conceive an idea to justify her delay in filing a patent application by showing that she was diligently reducing that invention to practice and testing it. The AIA removed that protection. In its place, the AIA adopted a "prior user right." 94 The prior user right creates a defense for a company that can show that it was already using the invention in a commercial manufacturing process more than

perform the disclosed algorithm."). Cf. HTC Corp. v. IPCom GmbH \& Co., KG, 667 F.3d 1270, 1272-73 (Fed. Cir. 2012) (where a means-plus-function software claim would have been invalid as indefinite for failure to disclose the algorithm that performed the functions of the software, but defendant waived the issue).

For discussion of these cases, see Sharon Barkume \& Michael R. Bielski, Strict Interpretation of 35 U.S.C. §112: Requires Universities to Examine Their Patenting Methods, 28 Touro L. Rev. 183, 197-98 (2012); Elise S. Edlin, Computer Claim Disarray: Untangling the Means-Plus-Function Doctrine to Eliminate Impermissible Functional Claiming in Software Patents, 28 Berkeley Tech. L.J. 417, 419-20 (2013); Christa J. Laser, A Definite Claim on Claim Indefiniteness: An Empirical Study of Definiteness Cases of the Past Decade with a Focus on the Federal Circuit and the Insolubly Ambiguous Standard, 10 Chi.-Kent J. Intell. Prop. 25, 37 tbls.6 \& 7, 39-41 (2010);

93 Cf. Timothy J. Holbrook, Possession in Patent Law, 59 SMU L. Rev. 123 (2006) (doubting the wisdom of an independent written description doctrine, but arguing that enablement could be strengthened to prevent overbroad claiming).

9435 U.S.C. §273. 
a year before a patent owner filed for a patent on that invention. ${ }^{95}$ The prior user right has so far been invoked rarely, likely because the requirement that the company already have implemented the process in its business more than a year before the patentee even files for a patent will not often be satisfied. ${ }^{96}$

A simple way to provide some protection to those who choose to build first and patent later would be to permit them to take advantage of the prior user right. Doing so would require only a modest expansion of the prior user right, extending it not only to companies engaged in "commercial use" of the invention ${ }^{97}$ but to those engaged in bona fide experimental use or efforts to reduce the invention to practice. Extending prior user rights to those in the process of developing or testing the invention when the patentee files her patent application will not give builders parity with paper patentees; the law will still put a thumb on the scale in favor of filing first and figuring things out later. But it would at least provide some protection to those independent inventors working to give the world not just a good idea but the means to

95 Id. While in many cases the company's use will be prior art that would bar that later patent, that is not always true. Secret commercial uses of the kind that often occur with process patents are not "public uses" that can bar a third party from getting a patent even though they can bar the user from getting its own patent. W.L. Gore \& Assocs., Inc. v. Garlock, Inc., 721 F.2d 1540, 1549 (Fed. Cir. 1983); Metallizing Eng'g Co. v. Kenyon Bearing \& Auto Parts Co., 153 F.2d 516, 520 (2d Cir. 1946).

96 The PTO conducted a Congressionally-mandated study of the prior user right in 2012 and found that it was not likely to be particularly disruptive to existing law.

http://www.uspto.gov/sites/default/files/aia implementation/20120113-pur report.pdf. Indeed, as of this writing the prior user right has not been applied in a reported decision. For a discussion of how the defense seems directed at manufacturing, and hence does not necessarily fit well with software, see Greg R. Vetter, Are Prior User Rights Good for Software? (working paper 2015).

9735 U.S.C. $\S 273(a)(1)$. 
make use of that idea. ${ }^{98}$ And the prior user right need not provide protection only against paper patents; the encouragement of experimentation should apply to all patents.

\section{Conclusion}

\section{Adam Gopnik writes:}

Originality comes in two kinds: originality of ideas, and originality of labor, and although it is the first kind that we get agitated about, we should honor the second kind still more. There is wit, made by the head and spun out into life; and work, created mostly by fingers engaging tools as various as tenor saxes and computer keyboards. It is an oddity of our civilization, and has been since the Renaissance, to honor wit more than work, to think that the new idea 'contributed' by the work matters more than the work itself. ${ }^{99}$

We want good ideas, but we also want practical implementations of those ideas. Without either, the patent system cannot serve its Constitutional purpose to promote the progress of the useful arts. ${ }^{100}$ Patent law has tilted increasingly towards encouraging ideas at the expense of those who take the time to develop and test their inventions. It is time to shift the balance not all the way in the other direction, but at least towards middle ground.

98 Cf. Robert P. Merges, A Few Kind Words for Absolute Infringement in Patent Law (working paper 2014), available at http://papers.ssrn.com/sol3/papers.cfm?abstract id=2464756 (arguing that the prior user right may ameliorate the costs of not having an independent invention defense while "encourag[ing] activity that has independent social value in the form of rapid movement toward the market.").

99 Adam Gopnik, Two Bands, New Yorker, Dec. 23-30, 2013, at 123. I am indebted to Jake Sherkow for drawing my attention to this quote.

100 U.S. Const., art. I, §8, cl. 8. 